\title{
Branding Employee Behavior, Corporate Brand Personality, Strategic Leadership, and Cultural Organizational Values to Develop Brand Sustainable Value in the Indonesian Banking Industry
}

\author{
Maria Mia Kristanti \\ Marketing Department of Business Faculty, Widya Mandala Catholic University, Surabaya 60253, Indonesia \\ The strategic role of branding in corporate competitive advantage is already proven, especially in service indus- \\ try. In contact with many consumers, employee has the central function to deliver good quality of service. This \\ marketing terms is known by the Employee-Based Brand Equity (EBBE). The research model was design to \\ analyze not only focus on the internal brand building behavior process management, but also conducted to the \\ other facets on brand citizenship behavior and behavioral branding for organizational competitive advantages. \\ The source of data interviewed via a field survey of 330 employees that work in bank as service organizations, \\ sourced from a market research Bank Indonesia data base list. A serial analysis methods of SEM, was con- \\ ducted to several model test, and also used LISRELL software for good statistically validation test. Good result \\ test was found for 27 of the hypothesis relationships confirmed validation for the proposed model.
}

Keywords: Employee-Based Brand Equity, Brand Building Behavior, Brand Citizenship Behavior, Behavioral Branding.

\section{INTRODUCTION}

The employee as the biggest part in the organizations could have the most important factors for building up an excellent service brand. ${ }^{1,2}$ This key role designates employee brand building behaviors in the organization. ${ }^{1,3}$ The terms of employee brand building behaviors was defined as 'employees' contribution effort in on and off the job to an organization's perceived customer branding strategies."1 This approach aims to positively influence behavior, create the brand more competitive, and targeted to effectively coordination to the behaviors of the employees good sense to their organization's branding. ${ }^{4,5}$

Based on a literature review, a brand can also boost the economic performance of an organization. ${ }^{6,7}$ More specifically, a strong brand justifies the higher price of a product or a service because a strong brand can evoke many associations, emotions and qualities, which promise tangible and intangible benefits to the customer. This will lead to the fact that well-established brands can increase the cash flow of a company. ${ }^{8}$ Additionally, a brand also has the ability to facilitate the process of obtaining information for the customer because the perceived complexity of market offers can be reduced, which leads to lower transaction costs for the customer. ${ }^{6}$ In addition, a well-known brand can act as a risk reducer by reducing the perceived risk of the customer in relation to product safety, technical support and service, financial risk and social risk. ${ }^{6,7}$ Furthermore, a strong brand can provide the company with the ability to stand out from the competition..$^{6,8}$

\section{THEORETICAL REVIEW}

Behavior of employees can support the brand building process of an organization, and how they can engage in creating strong brands are summarized under the term of employee brand building behaviors. ${ }^{1,9}$ The definition of employee brand building behaviors referred as "employee's contribution (both on and off the job) to the organization's customer-based branding strategy." Additionally, employee brand building behaviors is the reinforcement, strengthening as well as the creation of a favorable brand image for products and organizations. ${ }^{9}$ Principally, scholars constitute employees, who are heavily engaged in building up the brand as "brand ambassadors,"3 or "brand champions."1

The more the employees well known and realize their corporate brand values, more commitment level to the brand achieved and ready to demonstrate their corporate brand oriented 
behavior. ${ }^{10}$ The terms of internal branding process must be taken, with major implementation in socialize deeply on the organization communication systems and marketing programs. ${ }^{5}$ The corporate brand focus must have accepted and agreed by all the organization member, to make all of the objective of the organization running by right order and the right employees. ${ }^{11,12}$

Branding the employees' behaviour has strategic impact for corporation due to its crucial role in transmitting the organizational brand's values to external stakeholders. ${ }^{13}$ Further, the communication theory also underpin the importance of employees for shaping the corporate culture as corporate branding. ${ }^{13}$, 14 The role of core values are significant for corporate sustainable performance, and the organization need an alignment between the core values, as to build strong corporate brand. ${ }^{15}$

Organizational citizenship behaviour can described as the employees self-individual contribution behaviours outside their formal role on their organizational value of expectations. This rare behavior are various to the organizational formal remmuneration system, and enhances the customer perceived reputation and branding performance of the organization. ${ }^{16}$ Brand citizenship behaviour is more than as a part of organisational citizenship behaviour, but goes beyond the scope of organizational citizenship behaviour as it also includes stakeholders standardized fullfilment of every employee behaviours. Brand citizenship behaviour is an aggregate construct which describes those generic employee behaviours that enhance the brand identity. Employee's behaviors are critical for the consumer-based brand equity, by the placing position service employees which locate at the interface between the brand promise and brand delivery to the consumer heart and mind, in order to create well service brand associations. ${ }^{8}$

A firm develops this internal branding or internal marketing to fortify its employee-based brand equity. ${ }^{6,17}$ By promoting and educating the brand to employees, internal branding helps employees clarify their roles in building and delivering brand attributes associated with the products and/or services they sell and can therefore encourage them to think about the brand more consciously. In other words, employees can make a powerful connection to the organization's products and/or services ${ }^{18}$ and learn their place in 'the picture, ${ }^{19}$ which leads to employees' commitments to the corporate brand. Moreover, given that internal branding is seen as a means to build powerful brands, ${ }^{5}$ it helps the organization acquire a sustainable and competitive advantage, ${ }^{6}$ and eventually allows the organization to differentiate itself from its competitors. ${ }^{8}$

The main focus of employee branding in servicing is highlight on the employees' role in creating and maintaining the brand attributes associated with the organization's reputation and service performance. ${ }^{18}$ The activities implied by the label employee branding, because these organizational action are intended to impress brand attributes onto the work behavior of their employees, who are then expected to infuse service brand attributes throughout their work in order to deliver good service quality. ${ }^{18}$ Further, the employees' knowledge and understanding of a brands image is the key criteria with employee branding. This is influenced by the internal and external messages of the organization. ${ }^{9}$ The broad definitions of employee branding referred to the strategic branding process which creates, negotiates and enacts sustainable relationships between organization and its new potential and existing employees under the influence of the total corporate value contexts which aims to co-creating sustainable self-values for the individual, the organization, and consumer. ${ }^{20}$

In successful service organization, the way employees behave which take the consumer and companies first, are organizational assets, as buildingup an iconic service advantages company. The such positive impact of the employees' behavior can enhance organizational reputation, and at free cost. ${ }^{21}$ Further implication is, the employee's family and friends can also act as the thirdparty endorsers for the organizational reputation. ${ }^{22}$ In the company identity building, having a good employer as their main reputation can boost the employees' commitment, working motivation, and sense of engagement. These elements can generate an excellent job achievement and have a strong impact on organizational competitive advantages. ${ }^{23}$

The brands play a strategic role as a well-suited tool on business which engage the corporate sustainability, in their possibility of a firm to occupy a certain sustainable sources. Closing the gap between claimed concern and actual consumer behaviour outside

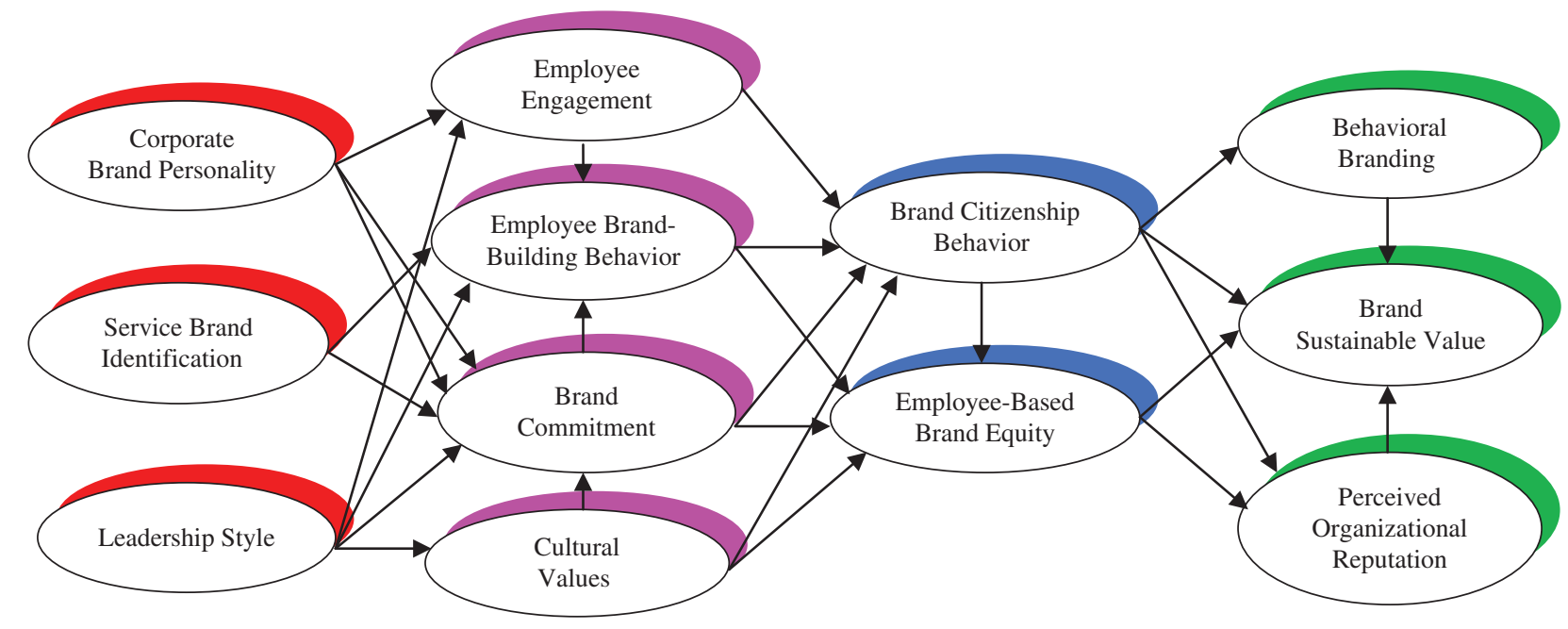

Fig. 1. Conceptional model. 
the organization, need more marketing effort in managing the brands, as the centre-piece corporate long lasting performance in the future. The brands must intimately involved to everyday consumers' lives, and thereby find ways to embed sustainability into individuals' customized value consumption. ${ }^{24}$ In this step, the brands become a tool to integrate sustainability into consumption, which provide consumers with emotional and social well-being, also seamlessly fit into the post-modern consumer's identity-creation behavior. ${ }^{25}$ The organization than turns into an excellent service-provider, not just a seller of goods, with its main mission to facilitate consumers' attempts in create a differentiation value for themselves, and manage to live a better life in an increasingly dynamic world. ${ }^{26}$

\subsection{Conceptional Model}

See Figure 1.

\subsection{Hypotheses}

The underlining several hypotheses' formulation, can be written in order bellow the Table I.

\section{METHODOLOGY}

One important objective of this paper is, to analyze the the research model, and explain all the hypotheses purposed. A quantitative survey method was chosen. The methodological

Table I. Sum of hypotheses.

\begin{tabular}{|c|c|}
\hline No. & There is a positive correlation between. \\
\hline 1. & Corporate Brand Personality and Employee Engagement \\
\hline 2. & $\begin{array}{l}\text { Corporate Brand Personality and Employee Brand-Building } \\
\text { Behavior }\end{array}$ \\
\hline 3. & Corporate Brand Personality and Brand Commitment \\
\hline 4. & $\begin{array}{l}\text { Service Brand Identification and Employee Brand-Building } \\
\text { Behavior }\end{array}$ \\
\hline 5. & Service Brand Identification and Brand Commitment \\
\hline 6. & Leadership Style and Employee Engagement \\
\hline 7. & Leadership Style and Employee Brand-Building Behavior \\
\hline 8. & Leadership Style and Brand Commitment \\
\hline 9. & Leadership Style and Cultural Values \\
\hline 10. & $\begin{array}{l}\text { Employee Engagement and Employee Brand-Building } \\
\text { Behavior }\end{array}$ \\
\hline 11. & Cultural Values and Brand Commitment \\
\hline 12. & Brand Commitment and Employee Brand-Building Behavior \\
\hline 13. & Employee Engagement and Brand Citizenship Behavior \\
\hline 14. & $\begin{array}{l}\text { Employee Brand-Building Behavior and Brand Citizenship } \\
\text { Behavior }\end{array}$ \\
\hline 15. & $\begin{array}{l}\text { Employee Brand-Building Behavior and Employee Based } \\
\text { Brand Equity }\end{array}$ \\
\hline 16. & Brand Commitment and Brand Citizenship Behavior \\
\hline 17. & Brand Commitment and Employee Based Brand Equity \\
\hline 18. & Cultural Values and Brand Citizenship Behavior \\
\hline 19. & Cultural Values Value and Employee Based Brand Equity \\
\hline 20. & $\begin{array}{l}\text { Brand Citizenship Behavior and Employee Based Brand } \\
\text { Equity }\end{array}$ \\
\hline 21. & Brand Citizenship Behavior and Behavioral Branding \\
\hline 22. & Brand Citizenship Behavior and Brand Sustainable Value \\
\hline 23. & $\begin{array}{l}\text { Brand Citizenship Behavior and Perceived Organizational } \\
\text { Reputation }\end{array}$ \\
\hline 24. & Employee Based Brand Equity and Brand Sustainable Value \\
\hline 25. & $\begin{array}{l}\text { Employee Based Brand Equity and Perceived Organizational } \\
\text { Reputation }\end{array}$ \\
\hline 26. & Behavioral Branding and Brand Sustainable Value \\
\hline 27. & $\begin{array}{l}\text { Perceived Organizational Reputation and Brand Sustainable } \\
\text { Value. }\end{array}$ \\
\hline
\end{tabular}

Table II. Reliability test of manifest variable.

\begin{tabular}{lcc}
\hline Variable & Cronbach's alpha & Category \\
\hline CBP & .987 & Reliable \\
SBI & .977 & Reliable \\
SL & .875 & Reliable \\
EE & .928 & Reliable \\
EBBB & .951 & Reliable \\
BC & .886 & Reliable \\
CV & .910 & Reliable \\
BCB & .885 & Reliable \\
EBBE & .876 & Reliable \\
BB & .968 & Reliable \\
POR & .989 & Reliable \\
BSV & .996 & Reliable \\
\hline
\end{tabular}

reason is, it provides an time-effective and cost-efficient procedures in collecting data with huge populations. The field questionnaire was carefully collected due to its advantages of originality and quality in given information.

In March 2015, a survey was conducted with 350 randomly selected employees from diverse work units of a Bank Indonesia 10 biggest bank in Indonesia. The total sum of 330 employees fill completed the survey, which response rate calculation result of $80.0 \%$. The respondents were 40 years majority, and the job position were held approximatelly 15 years. A total of $42 \%$ of the respondents were women and 58\% were men. The educational level indicate $80 \%$ of the respondents held a college degree. The job position of the respondents were employees from various levels, with the composition $17.8 \%$ no managerial skills needed, $36.5 \%$ lower managerial, and $42.7 \%$ middle managerial level and above. The company has government rated status as the most trusted bank by more than 200 million banking customers in Indonesia.

The structural questionnaire employs 'Likert-scale' questions which consist three domains, including employees' perception of management leadership, corporate reputation, and sense of empowerment, and questions on employees demographic profile. For the good preparation, the questionaire was distributed to 30 employees first. A convenience sampling method from Bank Indonesia 10 most biggest market share in Indonesia. The respondent also motivated with some details' explanation and rewards, to filtering the good validity of the instrument. The accuracy of every details' was ensure by not any of the questionaire left blank, or less clarification with the research questions. Otherwise, the data become useless, and the same step should have taken again with another person. There is only three items were revised to minimize bias. Also the 7-point 'Likert-scale' were applied to all the variables observed, to have a better quality of research findings.

\section{RESULTS AND DISCUSSION}

The new version of SPSS 21 was used in the whole statistically set of research test, to generate reliability analysis, factor loading, and Cronbach's alpha of employee branding in organizational and dimensions of brand sustainable value. As already discussed in the theoretical part that the basic aim of this study is to examine the relationship among corporate brand personality and brand sustainable value.

Table III. Coefficient of determination model summary.

\begin{tabular}{lcccc}
\hline Model & $R$ & $R$ square & Adjusted $R$ square & Std. error \\
\hline 1 & 0.989 & 0.978 & 0.980 & 0,0012 \\
\hline
\end{tabular}


Table IV. Hypotheses Tests of F ANNOVA.

\begin{tabular}{lccccc}
\hline Model & Sum of squares & Df & Mean square & $F$ & Sig. \\
\hline 1 Regression & 79.77 & 40 & 1.080 & 1899.07 & 0,000 \\
Residual & 0,000 & 57 & 0.000 & & \\
Total & 85.98 & 95 & & & \\
\hline
\end{tabular}

Cronbach Alpha Value are exceeding than 0.70, this mean that all of the indicator research were classified as reliable.

The Table III shows the high correlation between all the research variable, as indicated by the value of $R$ Square 0.978 . In other words, CBR can give a good explanation of influence for BSV. Linear regression analysis has been carried out to analyze the effects of twelve variables of brand as sustainable values on Indonesian Banks. There are some major findings of regression analysis for each hypothesis of the study.

$F$-Value shows that the research models were fit with all the data. As $F$-Value of 1899.07 is greater than probability base value of $0.000 \leq 0.001$, which means the research data were also qualified. The test of all of the hypotheses in this research can be a good evidence that prove all of the 27 hypotheses were true. This also proved that the research literature background was classified as eligible. $F$-Value shows that the research models were fit with all the data. As $F 0$-Value of 58.19 is greater than probability base value of $0.000 \leq 0.001$, means the research data were also qualified.

The test of all of the hypotheses in this research can be a good evidence that prove all of the 27 hypotheses were true. This also proved that the research literature background was classified as eligible. $F$-Value shows that the research models were fit with all the data. As $F 0$-Value of 58.19 is greater than probability base value of $0.000 \leq 0.001$, means the research data were also qualified.

Table V. Hypotheses tests.

\begin{tabular}{lccccc}
\hline Test & Variable & Estimate & Critical ratio & $t$-table & Category \\
\hline $\mathrm{H}_{1}$ & CBP-EE & 97,05 & 7,63 & 1,96 & Accepted \\
$\mathrm{H}_{2}$ & CBP-EBBB & 67,30 & 8,25 & 1,96 & Accepted \\
$\mathrm{H}_{3}$ & CBP-BC & 89,78 & 0,27 & 1,96 & Accepted \\
$\mathrm{H}_{4}$ & SBI-EBBB & 87,99 & 3,12 & 1,96 & Accepted \\
$\mathrm{H}_{5}$ & SBI-BC & 95,19 & 8,10 & 1,96 & Accepted \\
$\mathrm{H}_{6}$ & LS-EE & 90,98 & 29,98 & 1,96 & Accepted \\
$\mathrm{H}_{7}$ & LS-EBBB & 76,80 & 10,19 & 1,96 & Accepted \\
$\mathrm{H}_{8}$ & LS-BC & 82,96 & 5,17 & 1,96 & Accepted \\
$\mathrm{H}_{9}$ & LS-CV & 93,01 & 8,63 & 1,96 & Accepted \\
$\mathrm{H}_{10}$ & EE-EBBB & 87,80 & 8,98 & 1,96 & Accepted \\
$\mathrm{H}_{11}$ & CV-BC & 70,98 & 9,27 & 1,96 & Accepted \\
$\mathrm{H}_{12}$ & BC-EBBB & 56,96 & 6,58 & 1,96 & Accepted \\
$\mathrm{H}_{13}$ & EE-BCB & 94,54 & 7,50 & 1,96 & Accepted \\
$\mathrm{H}_{14}$ & EBBB-BCB & 86,68 & 5,56 & 1,96 & Accepted \\
$\mathrm{H}_{16}$ & EBBB-EBBE & 47,80 & 6,59 & 1,96 & Accepted \\
$\mathrm{H}_{17}$ & BC-BCB & 86,60 & 5,89 & 1,96 & Accepted \\
$\mathrm{H}_{18}$ & BC-EBBE & 43,00 & 6,65 & 1,96 & Accepted \\
$\mathrm{H}_{19}$ & CV-BCB & 98,70 & 9,20 & 1,96 & Accepted \\
$\mathrm{H}_{20}$ & CV-EBBE & 78,12 & 8,76 & 1,96 & Accepted \\
$\mathrm{H}_{21}$ & BCB-EBBE & 76,99 & 9,12 & 1,96 & Accepted \\
$\mathrm{H}_{22}$ & BCB-BB & 97,19 & 8,10 & 1,96 & Accepted \\
$\mathrm{H}_{23}$ & BCB-BSV & 90,56 & 7,73 & 1,96 & Accepted \\
$\mathrm{H}_{24}$ & EBBE-BSV & 86,54 & 7,54 & 1,96 & Accepted \\
$\mathrm{H}_{25}$ & EBBE-POR & 76,53 & 5,17 & 1,96 & Accepted \\
$\mathrm{H}_{26}$ & BB-BSV & 64,05 & 7,63 & 1,96 & Accepted \\
$\mathrm{H}_{27}$ & POR-BSV & 79,65 & 8,25 & 1,96 & Accepted \\
\hline & & & & &
\end{tabular}

Table VI. Model-fit test.

\begin{tabular}{lccc}
\hline Goodness of fit index & Cut-off value & Model result & Category \\
\hline GFI & $\geq 0,9$ & 0,91 & Good Fit \\
RMSEA & $\geq 0,9$ & 0,98 & Good Fit \\
NFI & $\geq 0,9$ & 0,95 & Good Fit \\
IFI & $0,8 \leq \mathrm{IFI} \leq 0,9$ & 0,88 & Marginal Fit \\
CFI & $\geq 0,9$ & 0,97 & Good Fit \\
RFI & $\geq 0,9$ & 0,98 & Good Fit \\
\hline
\end{tabular}

The Table VI shows that the research models were classified as Good Fit, which means the research model were based on good, valid and updates relevant theoretical background.

\section{CONCLUSION}

Today, in an increasingly competitive marketplace, customer focus has become a major strategy for banks as a service firms. As a result, banks are focusing on nurturing to become Brand Champions for superior service delivery. As a result of a model fit test, regression and validation process, demonstrating reliability and validity, was realised. Discriminant validity between the twelve variables established the scale was measuring with three distinct dimensions. Each dimension contributes individually to an operationalization of CBP, SBI, SL, EE, EBBB, BC, $\mathrm{CV}, \mathrm{BCB}, \mathrm{EBBE}, \mathrm{BB}, \mathrm{POR}$, and $\mathrm{BSV}$, and collectively, the three dimensions represent the most comprehensive understanding of Brand Championship on banks as their majority role to give service as a crucial part for customer confidence and trust, which determine the market share of the banks. Further, these twelve variables load on a first order factor, supporting the notion of a common theme among these factors. Put in other words, as CBP is conceptualised as a first order latent construct, employees are required to express a high degree of each of the three dimensions in order to score high on BSV and emerge as a Brand Champion.

\section{References and Notes}

1. F. M. Morhart, W. Herzog, and T. Tomczak, Journal of Marketing 73, 122 (2009).

2. B. Löhndorf and A. Diamantopoulos, Working paper, University of Vienna, Austria (2012).

3. S. Henkel, T. Tomczak, M. Heitmann, and A. Herrmann, Journal of Product and Brand Management 16, 310 (2007).

4. C. King and D. Grace, European Journal of Marketing 44, 938 (2010).

5. K. Punjaisri and A. Wilson, European Journal of Marketing 45, 1521 (2011).

6. C. Burmann, S. Zeplin, and N. Riley, Journal of Brand Management 16, 264 (2008).

7. C. Lovelock and J. Wirtz, Services Marketing: People, Technology, Strategy, 7th edn., Prentice Hall, Upper Saddle River, New Jersey (2011).

8. K. Jean-Noël, The New Strategic Brand Management: Creating and Sustaining Brand Equity Long Term. 3rd edn., Kogan Page, London (2008).

9. S. J. Miles and G. Mangold, Journal of Relationship Marketing 3, 65 (2004).

10. K. Thomson, L. de Chernatony, L. Arganbright, and S. Khan, Journal of Marketing Management 15, 819 (1999), Westburn Publishers Ltd.

11. W. Aurand, T. R. Bishop, and L. Gorchels, The Journal of Product and Brand Management 2/3, 163 (2005).

12. L. de Chernatony, S. Cottam, and S. Segal-Horn, The Service Industries Journal 26, 819 (2006).

13. L. T. Christensen and S. Askegaard, European Journal of Marketing 35, 292 (2001).

14. M. Morsing, Corporate Communications: An International Journal 11 (2006).

15. M. J. Hatch and M. Schultz, European Journal of Marketing 37, 1041 (2003).

16. P. M. Podsakoff, S. Mac Kenzie, J. Paine, and D. G. Bachrach, Journal of Management 26, 513 (2000).

17. I. Papasolomou and D. Vrontis, Journal of Product and Brand Management 15, 37 (2006). 
18. C. Mitchell, Selling the brand inside. Harvard Business Review (2002) Vol. 80, pp. 99-105.

19. A. Bergstrom, D. Blumenthal, and S. Crothers, Corporate Reputation Review 5, 133 (2002).

20. H. K. Aggerholm, S. E. Andersen, and C. Thomsen, Corporate Communications. An International Journal 16, 105 (2011)

21. M. T. Hansen, H. Ibarra, and U. Peyer, Harvard Business Review 104 January (2010)
22. B. M. Staw and L. D. Epstein, Administrative Science Quarterly 45, 523 (2000)

23. C. J. Fombrun, N. A. Gardberg, and J. M. Sever, The Journal of Brand Management 7, 241 (2000).

24. J. A. Ottman, E. R. Stafford, and C. L. Hartman, Environment: Science and Policy for Sustainable Development 48, 22 (2006).

25. A. Arvidsson, Journal of Consumer Culture 5, 235 (2005)

26. S. L. Vargo and R. F. Lusch, The Journal of Marketing 68, 1 (2004).

Received: 11 March 2016. Accepted: 14 March 2016. 